\title{
Management of Nursing Homes and Sheltered Housing in Finland
}

\author{
By Sirpa Salin* \\ Hannele Laaksonen ${ }^{\dagger}$
}

\begin{abstract}
The public sector is the largest producer of services for the elderly in Finland. The public elderly care management system has been criticized for having too many managers and levels. On the basis of the Finnish recommendation (MSAH 2013a), chief managers are responsible for the appropriate organization of the work, the reform of working practices and staff skills, the well-being and safety of the employees, the participatory management style, the management of multi-professional teams and a flexible allocation of the staff as needed. The present study aims to address this question: How do chief managers perceive their work image now and in the future? The study was undertaken at two Finnish public and two private nursing homes during the autumn of 2014. Data consisted of semi-structured interviews with four chief managers, analysed using the content analysis method. The job consisted of power and responsibility issues, preparing and executing decisions and participating in meetings. They reported that their jobs are multi-dimensional and demanding, and they are constantly working overtime. No matter how much they do, they feel inadequate. The chief managers' work is complex and fragmented. The ability to prepare for the future requires considerable attention, as it directly affects the reputation of the nursing home, which is difficult to recover. Reputation building includes the management, which is based on the values that appear in everyday work. Finland's rapidly diversifying population is a great challenge for which the country's health care system is not prepared. Future challenges in health care are divided into three main categories: the adequacy of resources (economic and human), the renewal of the service structure (legal obligations and their fulfillment), and the ability to prepare for social change (reputation building, internationalization and multicultural competence).
\end{abstract}

Keywords: Elder care management, Finland public and private nursing homes, Finnish eldercare law

\section{Introduction}

In 2013, the population of Finland was approximately 5.4 million, of which approximately $19.4 \%$ were over 65 years. The population is projected to grow to 5.8 million by 2030 , when people over 65 years will be around $25.6 \%$ of the population. The life expectancy for women is 83.8 years and 77.8 years for men. Life expectancy has risen by about 20 years in the world and in Finland, due to medical progress and rising living standards. In Finland, the number of the elderly will be exceptionally large due to historical reasons (Valkonen 2004).

The population is concentrated in a few growth areas, such as university towns and the metropolitan area. In more rural areas, the population is decreasing due to a higher mortality rate, migration and a low birth rate (Valkonen 2004). The aging of the population will also increase the need for services, which Finland is meeting with the new model of service structure, in which institutional care is reduced to a minimum and housing services are increased. The Finnish Elderly Care Law (MSAH 2013a), and the national recommendation (MSAH 2013b) provide the foundation for the development of services to meet customer needs.

\footnotetext{
${ }^{*}$ Post-doc Researcher \& Principal Lecturer, Tampere University of Applied Sciences, Finland.

${ }^{\dagger}$ Post-doc Researcher \& Principal Lecturer, Tampere University of Applied Sciences, Finland.
} 
The most important goals of The Finnish Elderly Care Law are: 1) to support the elderly population's welfare, health, functional capacity and independent living; 2) to increase and to strengthen the elderly's opportunities to participate in developing services; 3) to improve the elderly's ability to access high-quality social and health services; 4) to give advice for the use of other available services; and 5) to receive the services sufficiently in advance and before their functional capability decreases (MSAH 2013a).

\section{The Structure of the Elderly Care Service and the Direction of Change}

The public sector is the largest producer of services for the elderly in Finland and responsible for the care of the elderly services. The municipality can buy services from the private and third sectors through calls for tender. The municipality may also provide service vouchers to customers, who can then choose their own service provider (MSAH 2015, Koivisto 2011). The elderly care service structure includes home care, supported sheltered housing, supervised sheltered housing and residential care (Figure 1) (Johansson 2010, Teperi et al. 2009).

Figure 1. The Structure of the Elderly Care Service in Finland

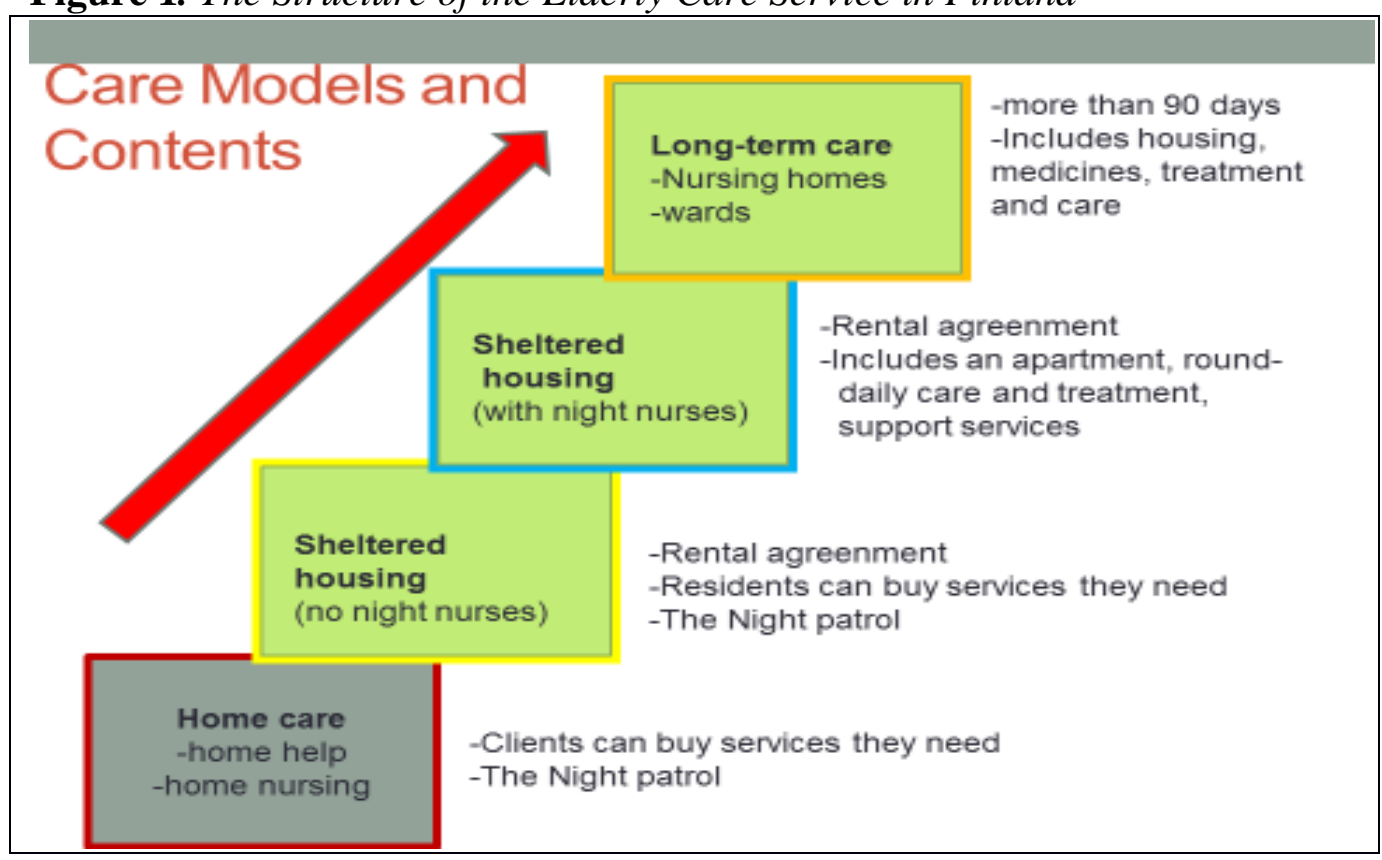

The current structure of the Finnish elderly service is inpatient-oriented, which is why the new Elderly Care Law (MSAH 2013a) has changed national targets. By 2017, 92\% of those aged 75 and older are to live at home, 7\% at sheltered housing with night nursing, and only $3 \%$ in inpatient care (Table 1). 
Table 1. Recommendations for the Elderly by 2017

\begin{tabular}{|l|c|c|c|}
\hline $\mathbf{7 5}+$ & $\mathbf{2 0 1 0}$ & $\mathbf{2 0 1 1}$ & $\mathbf{2 0 1 7}$ \\
\hline Living at home (\%) & 89,5 & 89,6 & $91,0-92,0$ \\
\hline Regular home care (\%) & 11,8 & 12,2 & $13,0-14,0$ \\
\hline Support for informal care (\%) & 4,2 & 4,4 & $6,0-7,0$ \\
\hline Sheltered housing with night nurse (\%) & 5,6 & 5,9 & $6,0-7,0$ \\
\hline Long-term care (\%) & 4,7 & 4,4 & $2,0-3,0$ \\
\hline
\end{tabular}

Source: www stm fi.

Vauramo's (2013) study has shown that dementia was the reason for requesting inpatient care in 59\% of cases, seeking service housing in 57\% of cases, and applying for home care services in 59\% of cases (Table 2). Current knowledge shows that dementia patients do not need institutional care. They may instead be treated in home care and district service housing. According to The Finnish Elderly Care Law, the elderly should be institutionalized only on medical grounds. Dementia is not a reason for medical care at a hospital. The average age of those entering elderly care services is quite high, reflecting the fact that the elderly in Finland are in generally good condition; their age-related diseases are treated, and they try to cope on their own or with the help of relatives for as long as possible (Table 2).

Table 2. The Main Reasons to Seek Treatment in Finland

\begin{tabular}{|c|c|c|}
\hline & $\begin{array}{c}\text { The Amount } \\
\text { of patients } \\
\%\end{array}$ & $\begin{array}{c}\text { The Average age } \\
\text { of the patients } \\
\text { Years }\end{array}$ \\
\hline $\begin{array}{l}\text { Nursing homes } \\
\text {-Dementia } \\
\text { - Unable to take care of oneself } \\
\text {-Somatic disease research and treatment } \\
\text {-Other reason }\end{array}$ & $\begin{array}{r}59 \% \\
19 \% \\
7 \% \\
15 \%\end{array}$ & 84 \\
\hline $\begin{array}{l}\text { Sheltered housing (with night nurse) } \\
\text {-Dementia } \\
\text { - Unable to take care of oneself } \\
\text {-Physical impairment - Difficulties to move } \\
\text {-Other reason }\end{array}$ & $\begin{array}{r}57 \% \\
20 \% \\
5 \% \\
18 \%\end{array}$ & 83 \\
\hline $\begin{array}{l}\text { Sheltered housing (no night nurse) } \\
\text { - Unable to take care of oneself } \\
\text {-Dementia } \\
\text { - Housing problems } \\
\text {-Other reason }\end{array}$ & $\begin{array}{r}32 \% \\
23 \% \\
7 \% \\
38 \%\end{array}$ & 80 \\
\hline $\begin{array}{l}\text { Long-term care } \\
\text {-Dementia } \\
\text {-Somatic disease research and treatment } \\
\text { - Unable to take care of oneself } \\
\text {-Other reason }\end{array}$ & $\begin{array}{r}59 \% \\
24 \% \\
8 \% \\
7 \%\end{array}$ & 82 \\
\hline
\end{tabular}

Source: Vauramo 2013.

There were two main services in 2010: lightweight home care and institutional care (24 hours) (Tolonen and Niiranen 2010: 58). Home care will be the largest and most important form of service in the future, so that customers 
will be able to live as long as possible in their own homes. Home care will be cheaper for society than institutional care, and can also be more humane for the customers and promote their active living for longer. Sheltered housing without a night nurse is also covered by home care. Sheltered housing with a night nurse is one part of the institutional care as well as the actual inpatient treatment (Johansson 2010: 5). The Finnish Elderly Care Law, which came into force in 2013, highlights the fact that medical reasons are the only criteria for both short and long-term hospitalization.

When an elderly person needs treatment or care, she or he will undergo tests to show the need for treatment. The assessment must be carried out in interaction with the older person, while respecting his or her personal views. The service needs assessment methods are:

- Physical: the Barthel Index (BI: ADL, IADL)

- Psychological: Geriatric Depression Scale (GDS-15)

- Cognition: Cohen-Mansfield Agitation Inventory (CMAI), MMSE

- Social: Center for Epidemiologic Studies Depression Scale (CES-D)

- Comprehensive Geriatric Assessment (CGA)

In long-term care, the personal care component is frequently provided with basic medical services, nursing care, prevention, rehabilitation and palliative care. Long-term care services can also be combined with lower-level care dealing with so-called instrumental activities of daily living (IADL) (e.g., domestic help, help with administrative tasks, etc.) (Finne-Soveri et al. 2010). In sheltered housing (with or without night nurses) the client can have their own room, a catering package (all meals), medicine, treatment and care, security services, clothing care and care accessories.

\section{The Amount and Structure of Staff in Elderly Care}

The National Recommendation (MSAH 2013b) suggests that service houses and nursing homes should have 0.50 staff members per one elderly person and 0.60 to 0.70 staff members per one elderly person in long-term care (Table 3 ). The index of staff dimensioning is calculated by dividing the number of staff with the number of inhabitants in such units. For example, at a unit with five nurses and ten customers the staff dimensioning is $0.5(5 / 10)$.

Table 3. The National Standards of the Amount of Employees

\begin{tabular}{|l|c|}
\hline The National Standards & The lower limit of the nurse/patient ratio \\
\hline Sheltered housing (with night nurses) & 0.50 \\
\hline Nursing homes & 0.50 \\
\hline Long-term care at hospital, wards & $0.60-0.70$ \\
\hline
\end{tabular}

Source: MSAH 2013a.

The national statistics indicate that in 2013 and 2014 the staff dimensioning was respectively 9 and 5,4 percentage points below the recommendation at private units. At public units the number was a little lower. However, both numbers were moving in the right direction, as units had been adding more 
staff in accordance with the quality of the recommendation (Table 4). There is a great deal of scientific evidence suggesting that the number of nurses affects the quality of nursing care (Andre et al. 2014). Significant predictors of quality nursing care are more nursing hours and better workplace conditions (TemkinCreener et al. 2010).

Table 4. The National Standards of the Amount of Employees in the Long Term Care

\begin{tabular}{|l|c|c|c|}
\hline 24 hour care & Recommendation & $\begin{array}{c}\mathbf{2 0 1 3} \\
\text { percentage points below } \\
\text { the recommendation }\end{array}$ & $\begin{array}{c}\mathbf{2 0 1 4} \\
\text { percentage points below } \\
\text { the recommendation }\end{array}$ \\
\hline Public units & MIN. 0,50 & 6,4 & 2,6 \\
\hline Private units & MIN. 0,50 & 9,0 & 5,4 \\
\hline
\end{tabular}

Source: Noro et al. 2012.

Home help staff is mostly made up of practical nurses, but in home health care, which is meant for clients with more chronic illnesses, the majority of the staff are nurses. At supported sheltered housing, where there are no night nurses, home care practical nurses take care of the residents. Sheltered service housing also provides night care, but about $76 \%$ of the staff members are practical nurses, $14 \%$ are nurses and $9 \%$ are other employees. The public and private sectors have a similar staff structure (THL 2011).

\section{The Management of Elderly Care}

Finland's public elderly care management system is multi-staged, from the lower management (supervisor) up to the director of the social and health sector (Figure 2). This system has thus been criticized for having too many managers. Local supervisors are responsible for their unit. The functional supervisor ensures that the work will be done. She or he is responsible for the effectiveness of the unit to the central management. Central managers usually have a number of units under their authority and their superiors. Chief managers are responsible for performance to their own service area industry leader. Industry directors have a number of service areas and are responsible to the director of the social and health sector. In the private sector, there are often fewer managerial stages (Laaksonen et al. 2012).

The qualification of the director at the social and health care sector is usually at least a master's degree, but quite often a $\mathrm{PhD}$. The chief management qualification is often a master's degree as well. A bachelor's degree is enough for the lower manager/supervisor, but they often have additional training in management. A master's degree from a university of applied sciences qualifies a person to apply for all managerial positions for which the qualification requirement is a master's degree.

On the basis of the National Recommendation (MSAH 2013b), chief managers are responsible for the appropriate organization of the work, the reform of working practices and staff skills, the well-being and safety of the employees, the participatory management style (which increases the well-being of employees), the management of multi-professional teams and a flexible allocation of the staff as needed. Researchers have found evidence that specific experiences are critical 
to the effective development of administrative competencies and leadership skills (Johs-Artisensi and Olson 2014, Kanste 2008). Scott-Cawiezell et al. (2005) pointed out that leaders have to reflect upon their own leadership styles to assure that developmental values can flourish.

Figure 2. The Multi-Stage System of the Public Sector Management in Finland

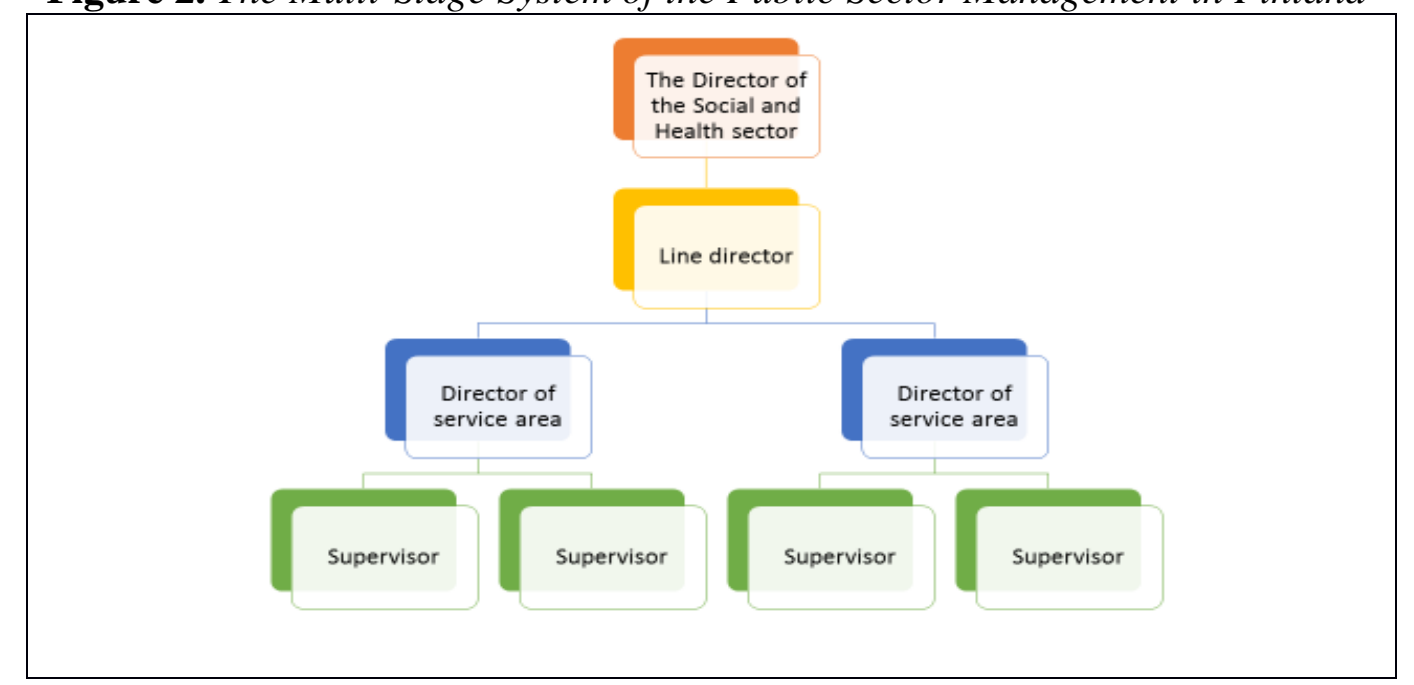

Source: Laaksonen et al. 2012.

According to first line managers, their leadership and management skills (Viitanen and Konu 2009, Abdelrazek et al. 2010) and psychological empowerment were quite high, but job satisfaction and psychosomatic health were lower (Abdelrazek et al. 2010). Their low job satisfaction is a challenge to the work environment, which needs to be improved to increase their job satisfaction and decrease stress. Research has shown that leadership style affects the quality of care (Jeong and Keatinge 2004, Andre et al. 2014). Work culture is very important for improving quality of care in nursing homes and changes are necessary to increase healthcare personnel's job satisfaction, empowerment, and autonomy (Andre et al. 2014). Chu et al. (2014) discovered that higher leadership practice scores were associated with a lower nursing turnover rate. Leadership practices and administrator turnover affect staff permanence (Chu et al. 2014). Participation, good communication, conflict resolution and empowerment were related to resident outcomes (Andre et al. 2014).

\section{Aims of the Study}

The study reported here is a part of a national research project on the work of chief managers in nursing homes in Finland. A major purpose of the national project is to disseminate good elderly care practices in Finland by investigating the chief managers' work image. The results can be used to develop the master's programme in Management of Social and Health Care at Tampere University of Applied Sciences.

The present article aims to address the question: How do chief mangers perceive their work image now and in the future? 


\section{Data Collection and Analysis}

The research data were collected during autumn 2014 in a mid-sized Finnish town. All four chief mangers were invited to participate. Two of them were working in the public sector and two in private companies. The chief managers were interviewed in their work places and the interviews were audio-taped and transcribed verbatim. The average duration of an interview was 1.5 hours.

Content analysis is a process used for analysing documents systematically and objectively. The aim is to generate a pattern that describes a phenomenon in a conceptual form (Hsieh and Shannon 2005). The researcher (S.S.) started the analysis by carefully reading the data. Themes describing the content of the job were chosen for the units to be analysed. Next, the data were listed under the various themes. The contents of the data under each theme were classified into subcategories (e.g. dialogue with stakeholders). The subcategories were combined into main categories (e.g. participation of the meetings). After a certain set of categories was completed, the other researcher (H.L.) evaluated the relevance, clarity, and completeness of the scene. The categories were discussed until agreement on the analysis was reached.

\section{Ethical Considerations}

The interviewees were selected on the grounds of expediency; they all had long personal experience with the phenomenon to be explored (Munhall 2001). The participants' names and addresses were delivered by the person from human relationship management after permission for the study had been obtained from the ethics committee of the city. The chief managers were sent a letter of invitation explaining the purpose and intent of the research. The completely voluntary nature of participation was made clear. The letter also confirmed that the researches would not obtain any other information about the institutions or the chief managers. After sending the letters, all recipients were contacted by phone within a few days. It was easy to make the appointments for the interviews because they wished to contribute to the research (Munhall 2001).

The informants were interviewed once. The atmosphere during the interviews was warm and open. The interviewees frankly related their working life histories and perspectives on the challenges of the future in elderly care.

\section{Results}

\section{Research Institutions}

All the institutions are located in the same town. Two of the institutions offer public services, one is a non-profit association and one is a private organization. These organizations have 128 to 450 long-term care places and up to 23 short-term places. All the beds are nearly always full and $67-90 \%$ of patients/customers are female. 
At the public organizations, $25 \%$ of the patients need full help, and $75 \%$ need moderate or great amounts of assistance with their daily living. At the private organization and non-profit association, all patients require moderate and great amounts of assistance. The non-profit association has a senior center where $60 \%$ of customers live independently and $40 \%$ need a little assistance. Dementia has become more common during past decades in Finland. At these organizations $80-100 \%$ of the patients/customers have memory disorders.

\section{Chief Managers at the Institutions}

All chief managers are women and their average age is about 50 years. One of the managers has a doctoral degree, and the others have master's degrees. One of them has two master's degrees. Their work experiences varied from 10 to 25 years. Two of the chief managers have worked as nurses and proceeded to directorial positions through many different jobs. All the chief managers have a significant amount of work experience and quite a lot of experience at different levels of management. One of the chief managers has been a president of a college and one a president of a university of applied sciences. One of the chief managers has worked as a priest. Health care leaders in Finland are well educated.

The interviewees were asked what kinds of skills the chief manager needs today. They reported that chief managers need many kinds of skills to cope with their work. For instance, they need interpersonal and general skills, legal expertise and empowerment of the staff. The chief managers also need skills in identifying the patients'/customer's needs. Nothing is as certain as change, which is why the chief managers must be able to manage change and development in their organization. When the organization is in constant change, the director must ensure the well-being of workers.

Today's challenges are great at the chief manager level, but what kind of person should the chief care manager be? Personal skills and human resource management skills are very important according to the results, as they lead large organizations and productivity demands are high. They need diverse experience but not necessarily the practical knowledge of nursing care. Administrative and organizational skills are starting points of the top manager skills and a wide vision of where they are going. Two of the chief managers have the opinion that the education needs to be at a university, but others believe that a university of applied sciences is the right training unit.

All the chief managers participated in planning the organization's strategy and were responsible for the implementation of the strategy. They also wrote the strategy based on talks with, for instance, the board of directors or the executive team and the staff. All the chief managers participated in developing the quality of care and quite often they were directors of the developing process. The chief managers needed to walk around the organization by observing the quality of services so that they could intervene if needed.

The top manager's work is very complex and fragmented (Table 5). They have many work areas with which to cope, such as project, strategic, quality and process management. Each area of the work will take approximately 10- 
$15 \%$ of their working hours. Organizational leadership requires the most time. This area contains the overall leadership of the organization. One of the chief managers was not able to describe the percentages (Table 5).

Table 5. Contents of the Work Areas

\begin{tabular}{|l|c|c|c|c|}
\hline & Interview & Interview & Interview & Interview \\
& $\mathbf{1}$ & $\mathbf{2}$ & $\mathbf{3}$ & $\mathbf{4}$ \\
\hline Organizational Leadership & $15 \%$ & $20 \%$ & The Director was & $60 \%$ \\
Human Resource management & $10 \%$ & $20 \%$ & not able to & $5 \%$ \\
Project Management & $15 \%$ & $20 \%$ & describe the & $10 \%$ \\
Strategic Management & $15 \%$ & $10 \%$ & percentages of & $10 \%$ \\
Quality Management & $10 \%$ & $10 \%$ & the Management & $5 \%$ \\
Process Management & $15 \%$ & $15 \%$ & and Leadership & $0 \%$ \\
Financial Management & $15 \%$ & $10 \%$ & & $5 \%$ \\
Management of Customer & $5 \%$ & $5 \%$ & & $5 \%$ \\
Relationship & & & & \\
\hline
\end{tabular}

\section{The Job Description of the Chief Manager}

The content of the job consisted of power and responsibility issues, preparing and getting things done and participating in meetings (Figure 3).

Figure 3. The Content of the Job

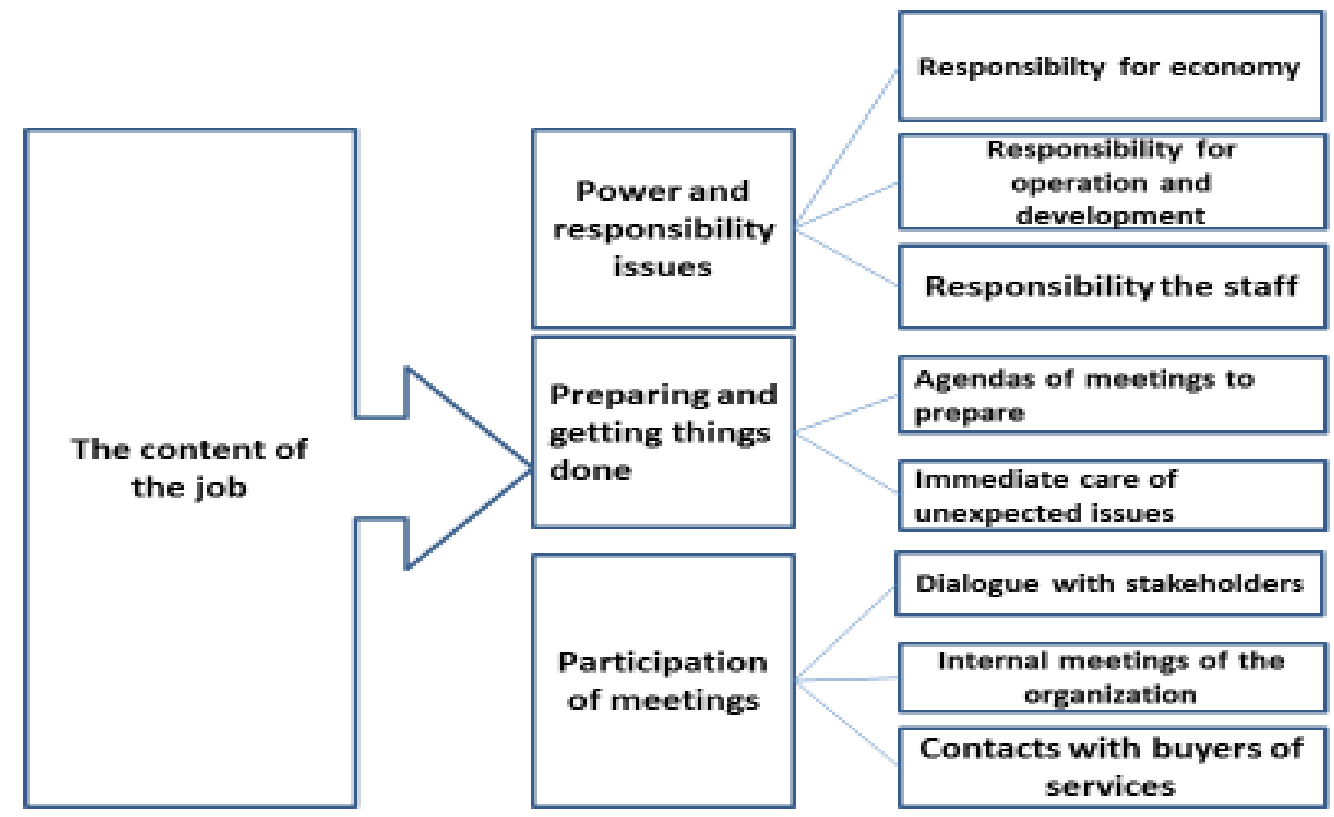

Power and responsibility issues were described by responsibility for economy and operation and development of elderly care services. The manager has the economic power to independently decide on acquisitions and expenses up to a certain amount of money without consulting the board. The economic responsibility is an important and omnipresent part of the manager's work. 
"Following the finances, following the amount of care days, following the staff levels" "2008 was an okay year. In 2009, the economic situation worsened and we needed permissions to fill temporary posts etc. We got much more paperwork. On top of that there's the routine business, like performance appraisals, which will take four days and must be done by March so the supervisors have time to do performance appraisals with their own staff. There's lots to do in this job and you have to be fast."

Responsibility for operation and development is a demanding part of the manager's job, as their perspective must extend years into the future, while the staff are focused on the present day. It is particularly challenging to operate in the middle of a large structural change no one can understand perfectly. The manager must however be able to read society's signs, as they are responsible for developing care through e.g., through the method of project management. The manager is also in charge of assessing the staff's knowhow, maintaining their professionalism and ensuring their long-term sufficiency. They also inform the staff on the board's decisions and ensure their execution.

Preparing and getting things done is a very time-consuming area. There are a lot of different kinds of meetings to be prepared. For instance, executive board meetings, board meetings and quality management meeting's agendas need to be prepared in time so that participants will have enough time to become familiar with the subject. Sometimes this causes a large workload because unexpected issues always arise that need to be treated immediately. Quite often, these cases are related to the staff or customers' feedback.

"the difficult thing about this work is how you're thinking from one to five years ahead, and then when you talk to the staff they're thinking about today ... you're thinking about some stuff in the future ..."

"... Sometimes you just have to work until you meet some deadlines, because no one else is going to do that job ..."

Participation in meetings requires dialogue with stakeholders, such as universities and trade schools. The aims of the joint development and research projects with them are to ensure good quality of care and staff expertise. Nursing students' practical training at the institutions is an important form of cooperation. Core activities are supported by various companies, e.g. pharmacies and medical supply and logistics companies. Cooperation with these stakeholders is very important.

Cooperation with national and international partners is becoming more and more common, especially in private companies.

"... there's maybe three or four business trips abroad a year. Cooperation with foreign partners is growing ..."

The chief manager holds a development meeting with the staff once a week. It is very important to know how the things are from both sides. These meetings enable face-to-face dialogue and give everybody a good opportunity to develop the quality of care. Negotiations with colleagues and superiors are very important to the chief managers because their work is solitary. 
Contacts with buyers of services are important and regular. Activities related to tendering are time consuming and getting more and more demanding. It is very challenging to provide quality services as cheaply as possible.

There is no typical work day for a chief manager. They never know in the morning what the day will bring. It can consist of meetings and their preparations in time, monitoring and controlling of contracts, developing, monitoring and controlling of activities and communication with customers and their loved ones. The chief manager has to be reachable at least by e-mail. The job description is multi-dimensional and demanding, which means that they are working overtime constantly. No matter how much the chief managers try to do they have a bad conscience.

"... You have to prioritize. You don't have time to go through things with your staff and you get a guilty conscience ..."

\section{Future Challenges in Elderly Care}

The future challenges are divided by three main categories: the adequacy of resources (economy, human recourses), the renewal of the service structure (legal obligations and their fulfillment), and the ability to prepare for the future (reputation building, internationalization and multicultural competence) (Figure 4).

Figure 4. The Challenges in the Future

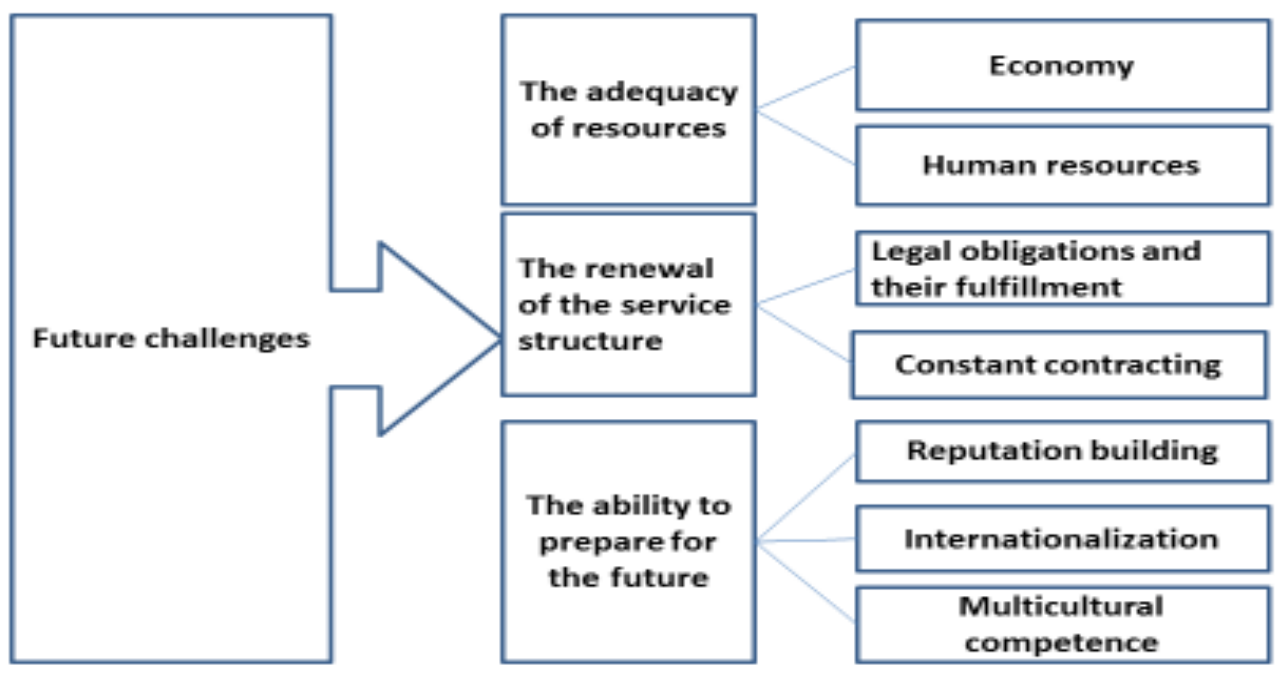

The adequacy of resources is one of the biggest challenges in the work of chief managers. Diminishing financial resources force them to think of new approaches, while also ensuring that the quality of care does not suffer. The chief manager needs to be innovative and able to think about things in a completely different way than before. The organization operates as a company, but a nonprofit one. 
"... tendering is constant challenge. Large companies can provide much cheaper prices, but whether their services are better is a different matter. We should really talk up the quality of our care and get people to demand it ..."

The adequacy of personnel is a major concern. The availability of staff that is committed and willing to develop their skills is not self-evident. The next generation of nurses does not necessarily value the same things as the older generation, and this creates flexibility in staff planning. Respecting and encouraging the diversity of young workers is of paramount importance so that they can be kept in the field and given the chance to develop their own work.

The structure of personnel is a difficult question. There has been a great amount of discussion in Finnish society about the requirements of the nurses working in elderly care. At the moment, we have registered nurses and practical nurses whose training is quite long. The arrival of a new professional group, such as a care assistant, is only a matter of time. The chief managers' responsibility is to guarantee the right nurse in the right place.

"... For instance, we're behing the Dutch, who have different levels of nurses. They have so called care assistants with less education. There is no such education in Finland yet and we require a degree from our permanent employees ... in the future we may not even find enough practical nurses, we'll need different levels, as they do in other countries ..."

The renewal of the service structure in social and health care is a profound change whose effects nobody knows. At the moment there are many legal obligations, such as the size of the rooms for elderly and security arrangements. The fulfillment of the requirements of the law is demanding and causes extra pressure in everyday life.

Constantly calling for bids is a very time-consuming and stressful area especially in the private sector. It is almost impossible to offer a good quality of care for elderly as cheaply as possible. Large companies provide services that are cheap, but the quality may be low. Elderly care nursing requires a lot of human resources - it is a question of nurse per patient ratio.

The ability to prepare for the future requires a great deal of attention. It is a question of reputation that has to be taken seriously. One's reputation may be lost only once. Maintaining it includes management, which is based on the values that appear in everyday work. The starting point for management is not to generate profit, but rather to support people by making their daily lives happier. Continuous service development is essential and applies to all employees.

Internationalization is a challenge and also a great opportunity for the future. Even now, international customers have asked to buy services and are ready to pay for them. Multicultural competence is needed more and more which means multicultural staff recruitment.

"... a Chinese official has contacted us and asked if we would organize interval treatment for their elderly and when I asked what that would require, he said 'a Chinese chef and someone who speaks Chinese' ..." 


\section{Discussion}

Finland is facing an economic crisis that also affects elderly care. The Finnish elderly care system is old fashioned and requires profound reform. Among other things, the system has been criticized for being centered on institutions and dealing with dementia patients by keeping them in bed in long-term care (Vauramo 2013). In international comparisons, this criticism can be seen as a spike in Finland's statistics (WHO 2013). Finland is currently in the middle of a large structural reform of the social welfare and healthcare systems, whose influence on the lives of private citizens and caregiving professionals is unknown.

There is a long tradition of social welfare and healthcare systems working separately in Finland, even if their clients are the same (Rokho 2012). Elderly care has been a part of social welfare, while home nursing has been a part of the healthcare system. The separation is organization-based and old-fashioned, making it an impediment to modernizing services (Tolonen and Niiranen 2010: 57). Many municipalities have combined their social welfare and healthcare systems, but there is still much work to do before they reach true cooperation.

Elderly care management has been criticized for being too hierarchical and bureaucratic. There is also lack of clarity about whether a manager should have a background in nursing or can come from any field. All the managers in this study were highly educated people with practical experience, some of whom felt that a manager needs a degree from a university. Finnish care managers are required to have studied administration in either a university or a university of applied sciences. Whatever their education, management is always part of the work community's reality (Nikkilä and Paasivaara 2007). The work community in turn is part of a larger operational environment, which presents constant pressure to change.

In this study, the managers' work consisted of several tasks that were framed by laws, regulations and schedules. Laws were sometimes seen as overly strict and even potential hindrances to developing care. Their work hours were not enough for doing everything, which made the managers feel inadequate. Questions of resources in both the financial and staffing areas are a large part of their work. The managers of private nursing homes were also required to call for bids on their services regularly, which was a demanding process. It is demanded that they provide high quality services cheaply (Merenheimo 2010: 263), which is not possible. Customer trust is very important to private service providers, because if they lose their reputation, it will take a long time to gain it back.

Staff dimensioning has been a topic of discussion in Finnish elderly care for a long time. There were parliamentary attempts to make a minimum ratio of 0.5 nurses per one elderly patient legally mandatory, but they were not successful. The ratio is currently only a recommendation that does not have to be followed. There are too few nurses in many municipalities. The work is tough and not valued highly. One of the major challenges today is finding staff with the right attitudes and qualities and managing to keep them in the organization. It is still not clear what a good staff structure is, what education level is required, or how the less educated staff members can be integrated into the whole. Managers 
require skills in reading their staff and careful leadership to utilize potential, express their views and modernize and develop their organization to meet the needs of everyday life (Nikkilä and Paasivaara 2007).

The quality recommendation is used by municipalities as a tool of strategic leadership and is also mentioned in reports of activities and evaluation reports, but its true influence depends on the municipality. The recommendation is often only used to assess the quality of local services, but comparisons to other municipalities nationally or internationally are rare. The recommendation has succeeded in making municipalities focus their elderly care services more to home care (Tolonen and Niiranen 2010).

According to this study, a manager should be able to think in a whole new way. As a visionary, they should read the signs sent by society and the wider world. Transformative leadership emphasizes a vision of challenging and rewarding staff, along with involving them and leading by example (Gromov and Brandt 2011). The manager's creativity is however limited by the amount of time required for routine work, as was suggested by this study. In talking about the challenges of the future, the managers mentioned internationalization and need for an international, or at least multicultural, capable staff. Of the four managers interviewed, only one had worked in international networks and formed international contacts as part of her job. A year after the interviews, all of Europe, including Finland, has been shaken by an unprecedented amount of refugees. Internationalism, offering services to people from different countries and multicultural capability in the staff have all become everyday things faster than anyone could have expected.

\section{Limitations of the Study}

The main difficulty with the method of content analysis lies in how well the researcher succeeds in extracting meaningful categories from the data and in demonstrating how they tie in with that data (Hsieh and Shannon 2005). The data collected for this study was small, running up to 46 pages, because only four chief managers were interviewed, which is a small number. Instead of generalizability, the aim was to describe and understand the phenomenon in focus (Hsieh and Shannon 2005). The analysis is described in this article in such a way that the reader can trace its various stages.

Credibility refers to the truthfulness of the results and depends among other things on the commitment of the researchers to the study (Polit and Beck 2006). The master's students carried out the interviews, and the researchers did the analysis. The research team discussed the findings together during the study process, so that obscure things could be specified together. Both researchers (S.S. \& H.L) in this study have extensive experience in working with elderly patients as chief managers. 


\section{References}

Abdelrazek F, Skytt B, Aly M, El-Sabour MA, Ibrahim N, Engström M (2010) Leadership and management skills of first-line managers of elderly care and their work environment. Journal of Nursing Management 18: 736-745.

Andre B, Sjøvold E, Rannestad T, Ringdal G (2014) The impact of work culture on quality of care in nursing homes - a review study. Scandinavian Journal of Caring Sciences 28: 449-457.

Chu CH, Wodchis WP, Mcgilton KS (2014) Turnover of Regulated Nurses in LongTerm Care Facilities. Journal of Nursing Management 22: 553-562.

Finne-Soveri H, Hammar T, Noro A (2010) Measuring the quality of long-term institutional care in Finland. Eurohealth 16(2): 8-10.

Gromov A, Brandt T (2010) Transformationaalinen johtajuus muutoksessa Tapaustutkimuksen kohteena organisaatiomuutos (Transformational leadership in change - A case study focuses on organizational change). LTA 1/11: 65-83. (In Finnish)

Hsieh H-F, Shannon S (2005) Three approaches to qualitative content analysis. Qualitative Health Research 9: 1277-1288.

Jeong SY, Keatinge D (2004) Innovative Leadership and Management in a Nursing Home. Journal of Nursing Management 12: 445-451.

Johansson E. (2010). The Long-Term care system for the Elderly in Finland. European Network of Economic. Policy Research Institutes. Retrieved from goo.gl/Fae Uku.

Johs-Artisensi J, Olson D (2014). Developing quality nursing home leaders. Nursing home excellence reflects significantly on the expertise and commitment of the administrators in charge (AITs) and their transition from student to leader. Long Term Living Magazine. www.ltlmagazine.com.

Kanste O (2008) The relationship between leadership and nursing personnel's willingness to exert effort, satisfaction with the leader and perceptions of leader effectiveness. Premissi 2: 42-48.

Koivisto R (2011) Well-being of a multi-disciplinary service. In Towards socially sustainable welfare: Ostrobothnian perspectives, 16-26. Proceedings of the University of Vaasa. Research Papers 295. Retrieved from goo.gl/qeL7Xq.

Laaksonen H, Niskanen J, Ollila S (2012) The Management basics in health care. Helsinki: Edita.

Merenheimo P (2010) Sosiaalipalveluyrittäjyyden ehdot ja mahdollisuudet: ulkoistamisen diskurssit palvelusetelityöryhmän muistioissa (Terms and Conditions of Social Service Entrepreneurship: Outsourcing Discourses in the Tables of the Service Task Force). Työelämän tutkimus 2: 252-266. (In Finnish)

MSAH (2013a) Quality recommendation to guarantee a good quality of life and improved services for older persons. Publications on the Ministry of Social Affairs and Health 19.

MSAH (2013b) The New Recommendation for a good quality of aging. Retrieved from goo.gl/PMgJ9U.

MSAH (2015) Services and benefits for old people. Retrieved from goo.gl/T6nqrN.

Munhall P (2001) Ethical considerations in qualitative research. In PL Munhall (Eds.), Nursing Research: A qualitative perspective, pp. 537-563. New York: National League for Nursing.

Nikkilä J, Paasivaara L (2007) Arjen johtajuus: rutiinijohtamisesta tulkintataitoon. Suomen sairaanhoitajaliiton julkaisuja (Everyday Leadership: From routine management to interpretation skills. Publications of the Finnish Nursing Association). Helsinki. 
Vol. 5, No. 1 Salin et al.: Management of Nursing Homes and Sheltered Housing...

Polit D, Beck C (2006) Essentials of Nursing Research. Methods, Appraisal, and Utilization (6th Edn.). Lippincott.

Rokho K (Edn.) (2012) National Profile of Occupational Health System in Finland. WHO Regional Office for Europe.

Scott-Cawiezell J, Jones K, Moore L (2005) Nursing home culture - a critical component in sustained improvement. Journal of Nursing Care Quality 20: 341-348.

Temkin-Greener H, Zheng NT, Cai S, Zhao H, Mukamel DB (2010) Nursing home environment and organizational performance association with deficiency citations. Medical Care 48: 357-364.

Teperi J, Porter ME, Vuorenkoski L, Baron JF (2009) The Finnish Health Care System: A Value-Based Perspective. Sitra Reports 82. Helsinki: Edita Oy.

THL (2011) The National Institute for Health and Welfare. Statistical Yearbook on Social Welfare and Health Care 2011. Retrieved from goo.gl/o23hHS.

Tolonen E, Niiranen V (2010) Steering of Local Elderly Services. Premissi 6: 52-58.

Valkonen T (2004) Elinajanodotteen kehitys, väestön vanheneminen ja tulevaisuuden terveysongelmat maailmassa ja meillä (Life expectancy development, population aging and future health problems in the world and us). Duodecim 120(18): 21732179. (In Finnish)

Vauramo E (2013) Miten Suomi selviää ikääntymisestä nykyisellä työvoimalla? (How does Finland find out about aging with the current workforce?). Retrieved from goo.gl/Zto2d3.

Viitanen E, Konu A (2009) Leadership style profiles of middle-level managers in social and health care. Leadership in Health Services 22(2): 108-120.

WHO - World Health Organization (2013) European Hospital Morbidity. Regional Office for Europe Database. Retrieved from goo.gl/vy $7 \mathrm{dVy}$. 